\title{
生物の形態形成と環境適応を模した住宅プラン生成システム に関する基礎的研究

\author{
A BASIC STUDY ON A HOUSE PLAN GENERATING SYSTEM \\ IMITATING ORGANIC MORPHOSIS AND ADAPTATION TO ENVIRONMENT
}

\author{
水嶋克典*，小松幸夫** \\ Katsunori MIZUSHIMA and Yukio KOMATSU
}

\begin{abstract}
This study builds and verifies a house plan generating system imitating organic morphosis and adaptation to environment. This system consists of the space formation system imitating morphosis and the condition adaptive system imitating adaptation to environment. The cellular automata and the genetic algorithms of artificial life are used in both systems. The result of the verification experiment verified that this system operates effectively in the house planning of a general scale, although there are some problems. One of them is that under the tight or complicated design conditions, the efficiency of the best plan generation declines. It is thought in the observation of verification experiments that these problems are improved by the diversity of the space differentiates many rooms, the adaptation of the parameter of genetic algorithms for each design condition, and the change of the plan generation procedure for every layer .
\end{abstract}

Keywords : morphosis, adaptation to environment, house, plan, artificial life, cellular automaton, genetic algorithm 形態形成, 環境適応, 住宅, プラン, 人上生命, セルオートマトン, 遺伝的アルゴリズム

\section{1 . 研究の背景と目的}

住宅設計において、実現叮能な多くの住宅プランの検討や複雑な設計 条件を満たす住宅プランの作成には、多くの人的資源を必要とする。こ れらの作業は、コンピュータを用いた自動設計による支援が適している と考えられる。これまで、プラン作成法に関する様々な研究が行われて きた。プランをモデル化して作成する手法は、吉田の直方体の空間を室 数と設計条件に基づき分割する空間分割型モデルによるプラン作成の研 究1 1231 、岡崎らの矩形室間の動線を最短にする空間連結型モデルによる プラン作成の研究などがある”。一方、工学の分野では、生物指向アプ ローチに見られるように、自己成長、自己修復、自己認識、進化、適応 など、生物の優れた機能を人「生命などの理論を用いて、人工物に応用 する試みも進んでいる5。建築分野では、青木のプラン作成と遺伝進化 のアナロジーについての考察がある6。これらを応用したプラン作成法 として、村岡らの遺伝的アルゴリズムを用いた平面形状の最適化に関す る研究》、山邀らの人工生命を用いた住宅平面空間構成と立体構成に関 する研究8191などがある。また、生物学の分野では、発生分子学などの 進展により、モデル生物をはじめとした生物の身体を形作る形態形成の 詳細も明らかになりつつある(10111。

本研究は、生物と住宅プランの構成と環境適応の類似に着目し、人士 生命を用いて、生物が細胞分裂を繰り这すことにより身体を形作る形態 形成と生物の環境適応を模した単位空間の分割増殖による空間連結型モ デルを用いた住宅プラン生成システムの一例の構築，その動作検証と動 作傾向の確認を目的とする。

\section{2. 住宅プラン生成システム}

\section{2-1. 生物と住宅プランの類似}

生物と住宅プランには、二つの類似がある。ひとつは、生物の身体構 成と住宅プランの空間構成である。生物は、細胞分裂を繰り返し、分化、 分裂制限、死滅など細胞を制御することにより、身体を構成し(形態形 成)、生物の身体は、頭一胸一足などの身体構成要素の接続関係をグラ フで表現することができる。同様に、住宅プランも、設計作業において、 必要な空間が作成、接続され、完成されたものは、玄関一廊下一居間な ど空間の関係をグラフで表現することができる。もうひとつは、生物の 環境適応と住宅プランの条件適応である。生物は、成長を調整すること により周辺環境に適坴する。更に、世代交代による淘汰を繰り这し進化 することにより、周辺環境に適応する。同様に、住宅プランは、設計条 件を満足し、住宅を取り巻く環境に適応する必要があり、設計作業にお いて、繰り返し修正、改良されることにより、設計条件に適合する。

\section{2-2. システム構築と検証の方法}

本研究における住宅プラン生成システムは、図1に示す様に、生物 の形態形成システムと環境適応システムを模做した空間形成システムと 条件適応システムを組み合わせた遺伝的アルゴリズムにより、住宅プラ ンを生成するシステムとする。

住宅の空間形成システムは、図 2 に示す様に、セルの配列変化 (分 裂)、周辺認知機能、条件判定機能により拡張したセルオートマトン, 空間構成とセル分裂パターンを情報化した遺伝子を用いる遺伝的アルゴ リズムにより、生物の形態形成システムを模做する。

\footnotetext{
$*$ 職業能力開発総合大学校建築システム工学科 講師・工修

** 早稲田大学理工学術院建築学科 教授・工博 

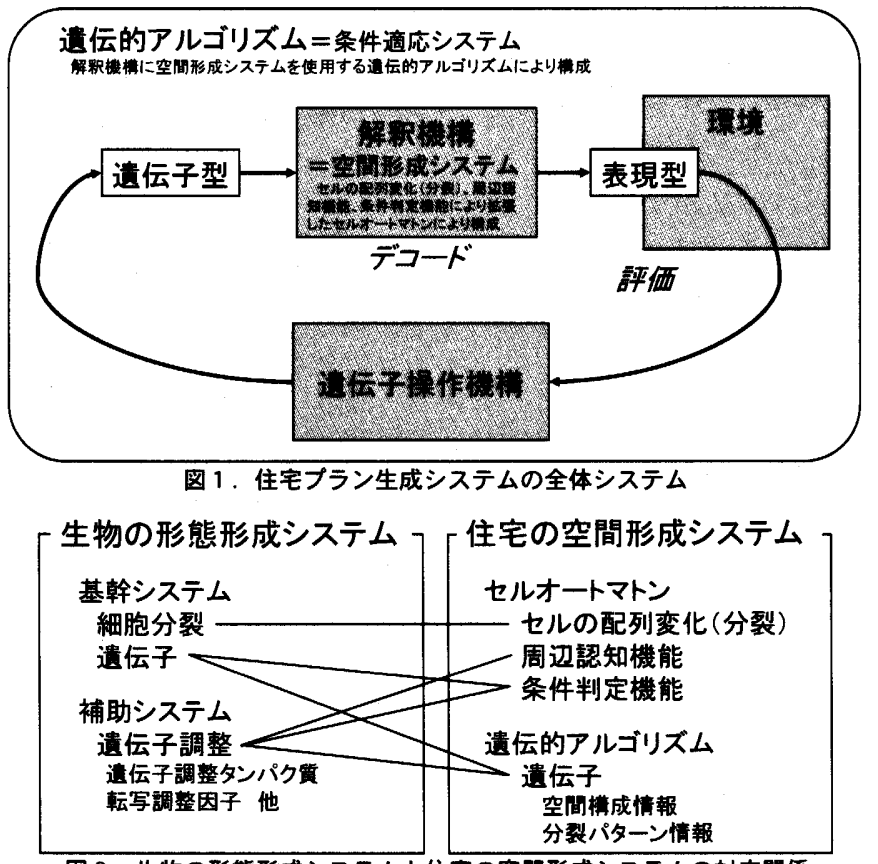

図 2. 生物の形態形成システムと住宅の空間形成システムの対応䦕係

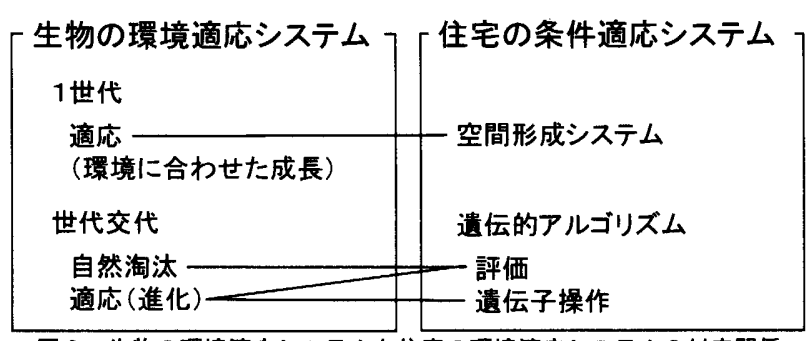

図 3. 生物の環境適応システムと住宅の環境適応システムの対応闌係

住宅の条件適応システムは、図 3 に示す様に、前述の空間形成システ 厶と世代交代による淘汰、適応(進化)から構成され、1世代の環境適 志システムは、空間形成システムにより、州代交代による生物の環境適 応システムは、遺伝的アルゴリズムにより模倣する。

本研究における住宅プラン生成システムの構築は、一般的な設計条件 を与えることにより、それらの条件に最も適合する住宅プランを生成す るシステムとすることを目標とする。動作検証は、構築したシステムに おいて、いくつかの異なる設計条件の住宅プランを生成する検証実験を 行い絬果を考察することにより行う。

\section{2-3. 住宅の空間搆成のグラフ表現}

本研究の住白プラン生成システムの対象とする住宅は、万建て住宅と 集合住宅の 1 住戸とする。住宅は、生活行為に対㐫した空閒と移動のた めの空開により構成される。これらの空問は、環境、機能、動線、ゾー ニングなどの条件により接続され、規模は、人体寸法、生活行為などに より決定される。また、住宅全体の規模は、敷地やコストによる制約の ため、ある程度の規模に収まる。空間規模を含めた住白の空間構成は、 敷地に接する道路からアプローチを経て、玄関を基点として各空間を接 続した図4に示すグラフとして表現することができる。

\section{2-4. 住宅プランのモデル化}

日本では、在来軸組構法木造住宅が普及しているため、住宅設計は、 1 辺の長さが 3 尺 $(910 \mathrm{~mm})$ 程度の正方形平面の単位空閒モデュールを 基本としたグリッドプランニングで行われることが多い。本研究では、 図 5 に示す様に、単位空間モデュールをセルオートマトンのセルに置き 換え、単位空間モデュール(セル)の集合を空間 (空)、空間の集合を

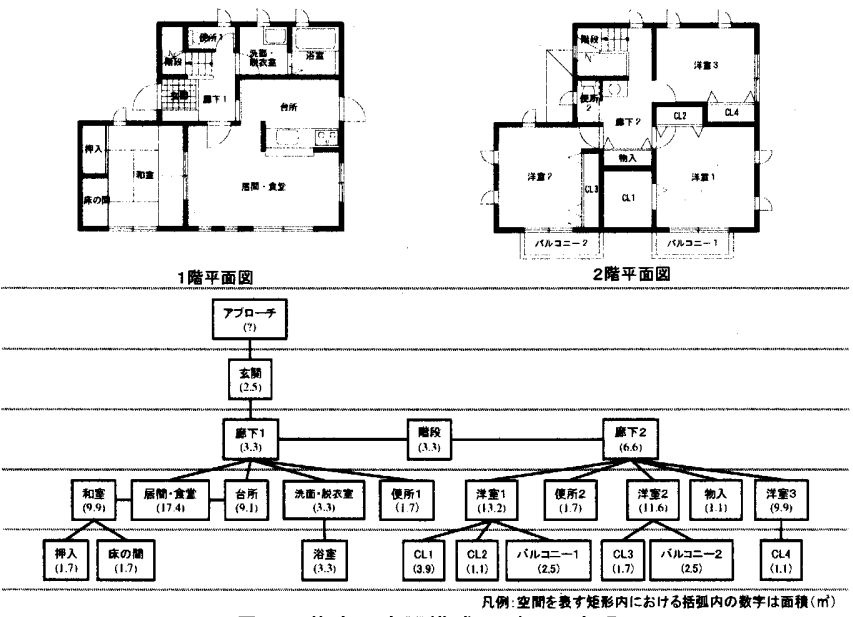

図 4、住宅の空間攜成のグラフ表現

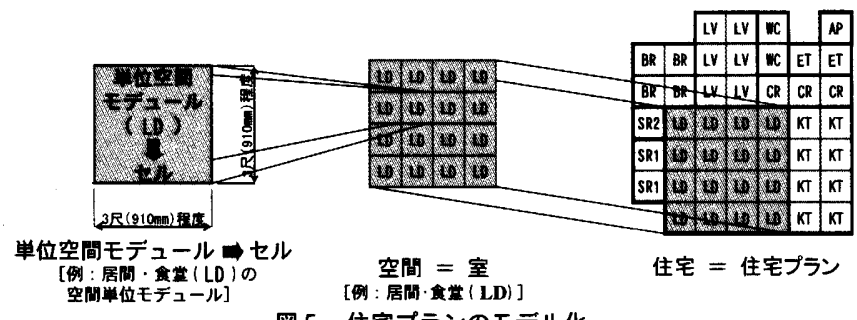

图 5 . 住宅プランのモデル化

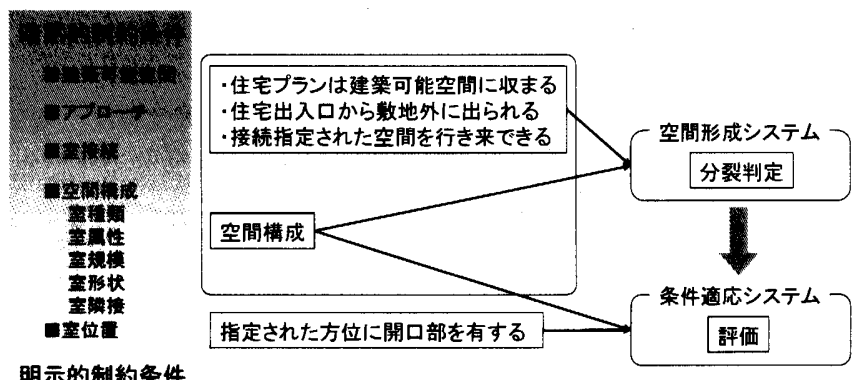

図 6、設計条件と空間形成・条件適応システムの闌係

住宅 (住宅プラン) とし、住宅設計を単位空間モデュール(セル)の積 み上げ行為と考える。また、本研究では、設計初期段階において、間取 り図を住宅の 3 次元空間を 2 次元平面で表現するものとして、建物規 模、機能的な空閣配置と空間演出を同時に検討し、建物ボリューム、外 観デザインを決定する計两・設計上重要なものと考え、設計初期段階に 作成される簡単な間取り図である敷地内の空間配置(室配置)を求める ことを目標とし、これを仮に住宅プランと呼ぶこととする。

\section{2-5. 設計条件と設定}

本研究では、設計条件を以下に示す項目とした。 (1)建築可能空間 (形状、規模、方位、アプローチ) (2)空間構成（室面積、室形状、室接続、室隣接） (3)室の外部開山部が面する力位(開山方位)

住宅設計の設計条件は、必ず尖現しなければならない基本的な制約条 件とプロジェクト每に指定される制約条件があると考えられる。住宅 は建築叮能空開内に収まる」など必ず実現させなければならない基本的 な制約条件を「暗黙的制約条件」それ认以外のプロジェクト毎に指定さ れる居間の外部開山部を南側にするなどの条件を「明示的制約条件」と する。しかし、住宅は建築可能空間内に入るという暗黙条件を満たして も、更に施主から建築可能空間内の住宅の配置位置を指定されるなど、 個々の設計条件は、図 6 に示す様に、暗黙的制約条件と明示的制約条件 の間に位置すると考えられる。 
本研究における住宅プラン生成システムは、図 6 に示す様に、条件適 応システムの評価を容易にするため、喑黙的制約条件寄りと考えられる 制約条件を空開形成システムに組み込むことにより、評価段階にて、出 来る限り暗黙的制約条件寄りの制約条件の評価を不要とする方針とし た。設計条件の詳細と各種設定を図 7 と以トに示す。

\section{2-5-1. 建築可能空間}

建築可能空間に関する条件は、「住宅は建築可能空間内に収まる」で あり、暗然的制約条件である。敷地、法令、周辺環境などにより、建築 可能空閒が指定される。次に建築可能空間の設定を示す。

(1)建築叮能空閒は、敷地の建築可能な範囲を正方形の空閒モデュール で分割する。(2)空閒モデュール寸法は、単位空間モデュール(セル)と 同寸法とする。(3)座標は、第 1 象限内とし、多層の住宅プランの場合、 層間に階高分の差がある層を設定する。図 7 の 1 の例では、 2 層の建築 可能空間を 0首 (1 階)、1 序 (2 階) と設定している。(4)空間モデュー ルに番号 (空間モデュールNo.) )付ける。(5)建築可能空間の道路境界 線に近い空間モデュールを接道空間モデュールとして設定する。

\section{2-5-2. アプローチ確保}

アプローチ確保の「住宅出入口から敷地外に出られる」は、暗黙的制 約条件である。アプローチ確保の方法は、空間形成システムに組み巡む 2 段階成長(1)出入口(玄関)の成長と出入口から接道空間モデュール まで屋外通路を確保するためのアプローチを生成する [第 1 段階成長]。 (2)住宅プラン全体は、出入口セルまたはアプローチの成長によりアプ ローチを確保した後に成長する[第 2 段階成長]) を利用する。本研究に おいて、アプローチ確保は、0層（1階）で行うこととした。

\section{2-5-3. 室接続}

室接続の「接続指定された室同士を直接連結して行き来できる」は、 喑默的制約条件である。室接続確保の方法は、(1)セルを単位空間モ デュールとし、1 辺の寸法を人が通行可能な開し部が設置できる 3 尺 $(910 \mathrm{~mm})$ 程度とする。(2)室の接続を確実に確保するため、セル分裂方向 には、ノイマン近傍を用いる。

\section{2-5-4. 空間構成}

住宅プラン生成システムにおいて、「空間構成」は、設計条件として 指定されるため、空間構成の「指定された空間構成を再現する」内の「指 定された空間構成」は、明示的制約条件であり、「空間構成を再現する」 部分は、システムが、必ず実現しなければならない暗黙的条件であると 考えられる。空間構成は、空間構成グラフに基づき、室番号、室略号、 室属性、室階層、室規模、室接続、室隣接を空間構成コードで記述し、 空間形成システムにて表現型にデコード、条件適応システムにより評 価·適応させることで再現する。廊下は、空間形成システムにより、様々 な規模と形状が作成可能なことから、廊下の室規模は、設計条件として 許容できる最大数を指定する。

\section{2-5-5. 外部開口方位}

「指定された方位に外部開口部を有する」は、明示的制約条件である。 指定された外部開口部は、指定された室の外部開口部が作成可能なセル (外部開口セル)の位置 (方位) と数量を条件適応システムの開口判定 により評価を行い確保する。図 7 の 5 .外部開口方位に示す住宅プラン は、居間・食堂 [LD] の南側、台所 [KT] の東側と南側の間口全長に、 外部開口部が作成可能と判断する。

\section{2-6. 解粎機構 [空間形成システム]}

解釈機構(空間形成システム)は、空間構成コードと遺伝子に基づき

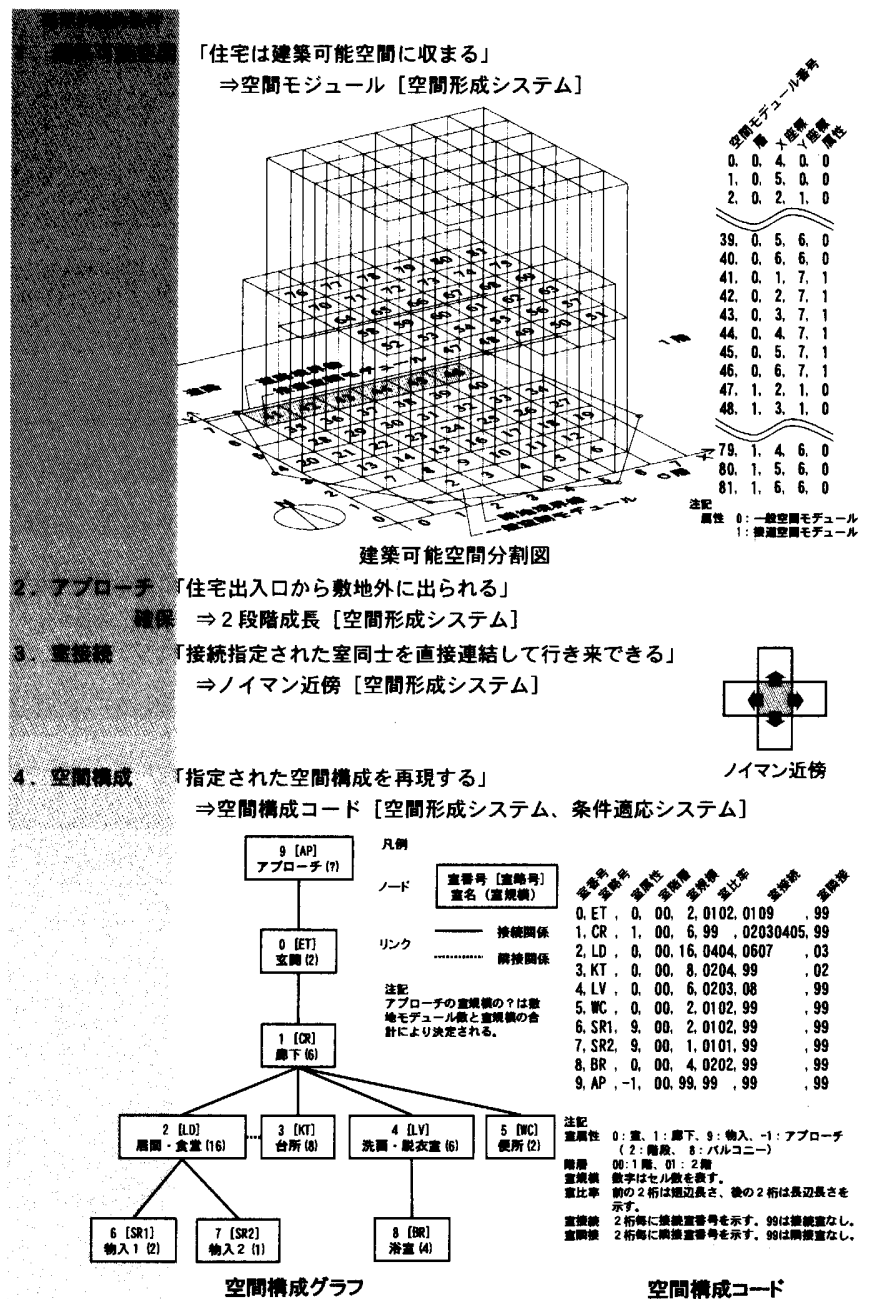

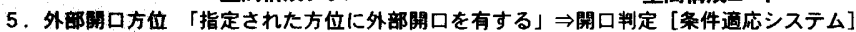

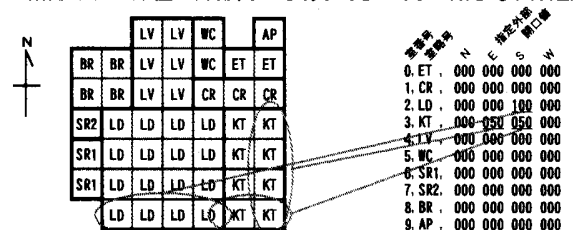
図 7.設計条件の詳細と各種設定

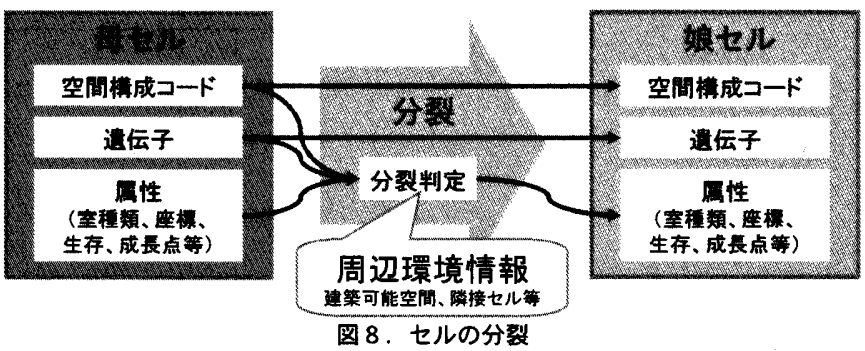

段階成長・セル分裂アルゴリズムなどを用いて、セルの分裂を繰り返す ことにより、住宅プランをデコードする。

2-6-1. セルとセルの分裂

セルは、図 8 に示す様に、空間構成コード、遺伝子、属性を持ち、こ れらと建築可能空間や隣接セルなどの周辺環境の情報による分裂判定に 基づき分裂する。

2-6-2. セル分裂アルゴリズム

セル分裂アルゴリズムを図 9 に示す。怆、セル分裂タイミングを指 示する0から1ずつ増加する分裂ステップを表す。0〜2分裂ステップ の具体的なセルの分裂の動作を図 10 に示す。 


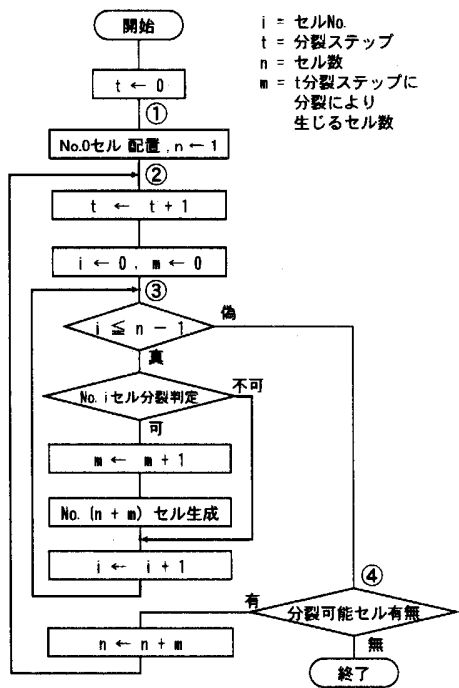

図 9. セル分裂アルゴリズム

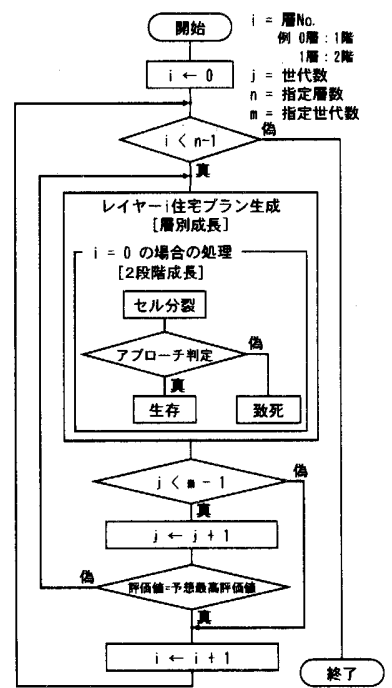

图 11 . 段階成長アルゴリズム
(1)初めに、0 層の建築可能空間にNo.0セルを配置する。 $[\mathrm{t} \leftarrow 0]$

(2)時間（分裂ステップ）を進める。[t๘t+1]

(3)セルの番号順に、分裂判定により分裂を決定する。分裂判定について は、後述する。

(4)全セルの分裂判定が終了した時点で、分裂可能セルの有無を確認し、 分裂可能セルがあれば(2に進み、なければセル分裂アルゴリズムを終了 する。

2-6-3. 空間種類別セル分裂パターン

セル分裂により住宅を構成する空間を生成するためには、空閒の種類 毎に異なる分裂パターンを必要とする。本研究では、住宅を構成する空 間を室、物入・バルコニー、アプローチ、廊下、階段に分類して、各空 間に表 1 に示す分裂パターンを設定した。各空問の分裂パターンには、 その空間の形成に必要な分裂可能な成長点と隣接セルなどに基づく分裂 判定による差異を与え、空問構成コードにて、室属性として設定する。

\section{2-6-4. 段階成長}

住宅プランの設計条件の奉現亡成长を確奏にするために、図 11 に示 す 2 種類の段階成長を導入する。2段階成長は、アプローチを確尖に確 保するため、No.0セルからアプローチセルを延ばし(第 1 段階成长)、 アプローチを確保した後、成長 (第 2 段階成产)を開始する。アプロー チが確保できなかった場合、その遺伝子は致死とする。層別成长は、層 毎の住宅プランの成長を確奏にするために、層每に最高評価值の遺伝子 を遺伝子操作から保護して、次層のプラン成長を開始する。

2-6-5. 遭伝子 [空間形成システム十条件適応システム]

遺伝子は、空間構成コードからセルの位置、成長方向、室生成のタイ ミング、廊下の分岐や长さの傾向など、住宅プランの形状を決定する成 長に関する情報として生成され、遺伝子操作機構により、設計条件に適 㐫する住宅プランを求めるために操作される。

\section{(1)这伝子の構成と表現}

遺伝子は、図 12 に示す様に、1つの位置遺伝子と層数分の遅延係 数・分岐閾值遺伝子の組から構成される全体遺伝子と空間構成コードに より組数が決定する順序・遅延・分岐・方向・回転・室種類遺伝子を 1 組とした成長遺伝子により構成される。遺伝子の表現は、十進整数を用 いる。

\section{(2) 遗伝子の生成と機能}

全体遺伝子である位置遺伝子は、住宅の出入口(立関) セル (No. . セ

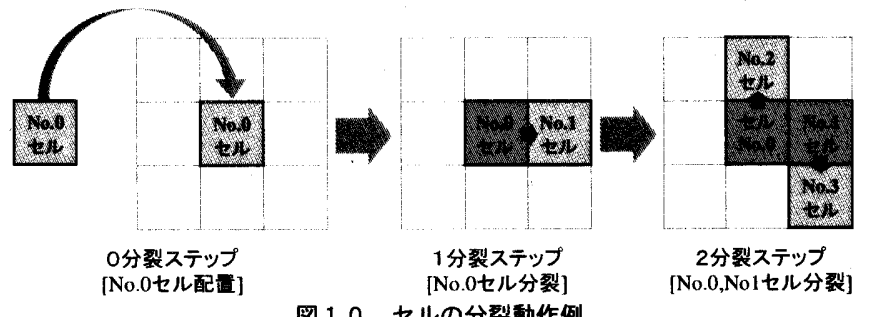

图 10. ○ルの分裂動作例

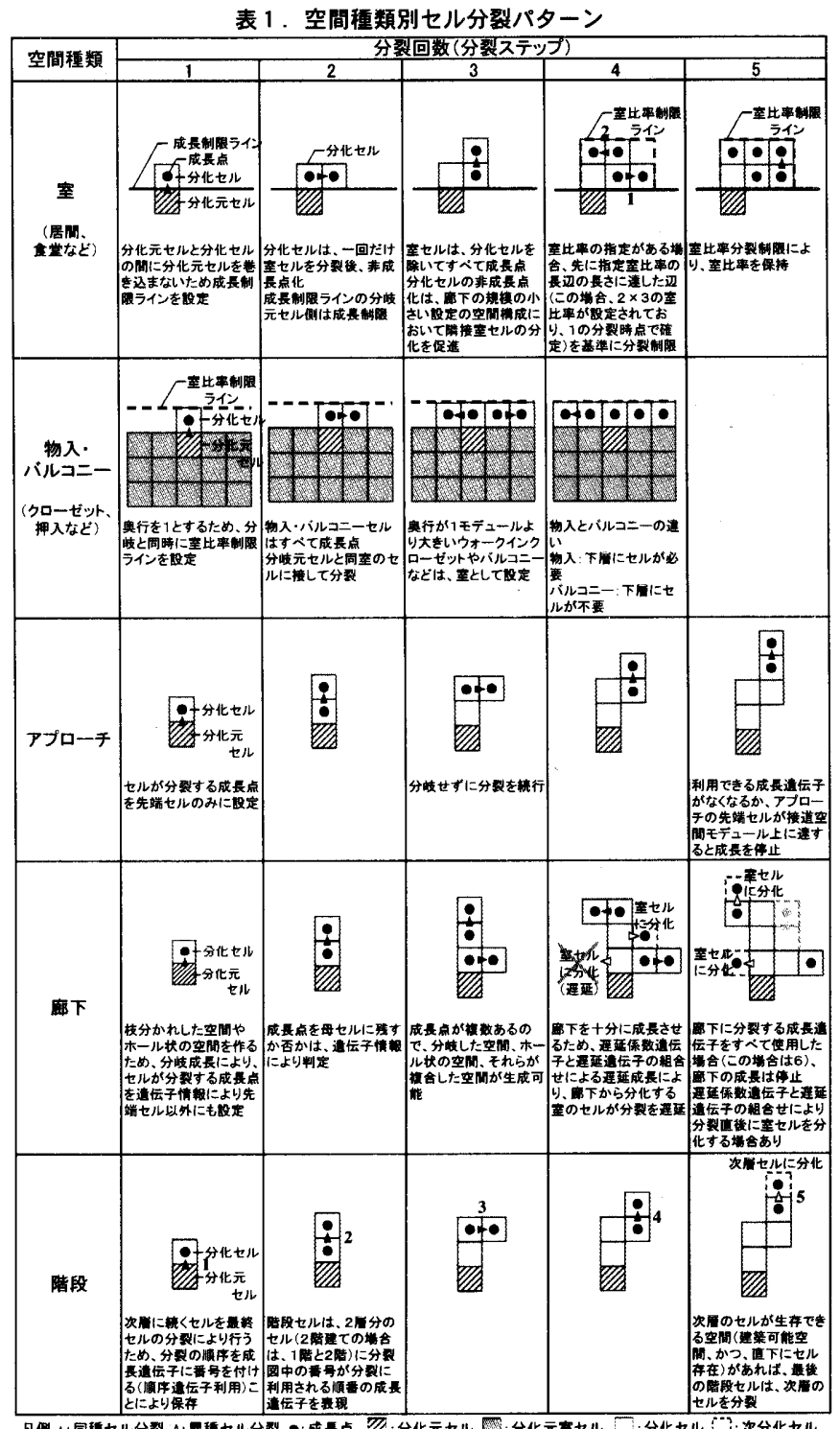

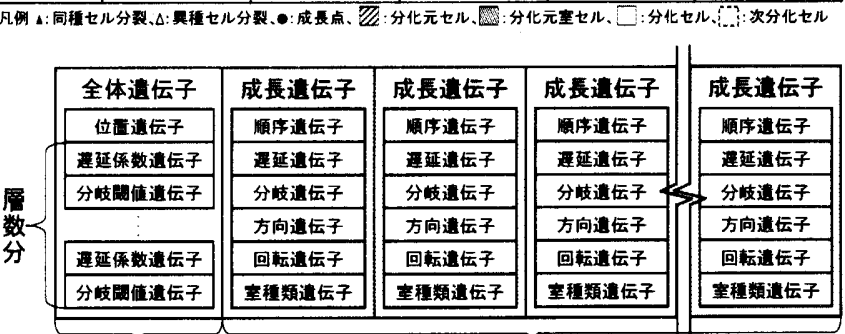

1 組の全体遺伝子成長遗伝子組数は空間権成コードにより決定 図 12 ，息伝子の權成

ル)が配置される0層の空間モデュールの番号を乱数によって生成し、 図 13 の位置遺伝子の機能に示す様に0層の空間モデュールへの配置に 用いる。同じく全体遺伝子である遅延係数遺伝子は、乱数により0〜20 を、分岐閥值遺伝子は、0〜99を生成する。 


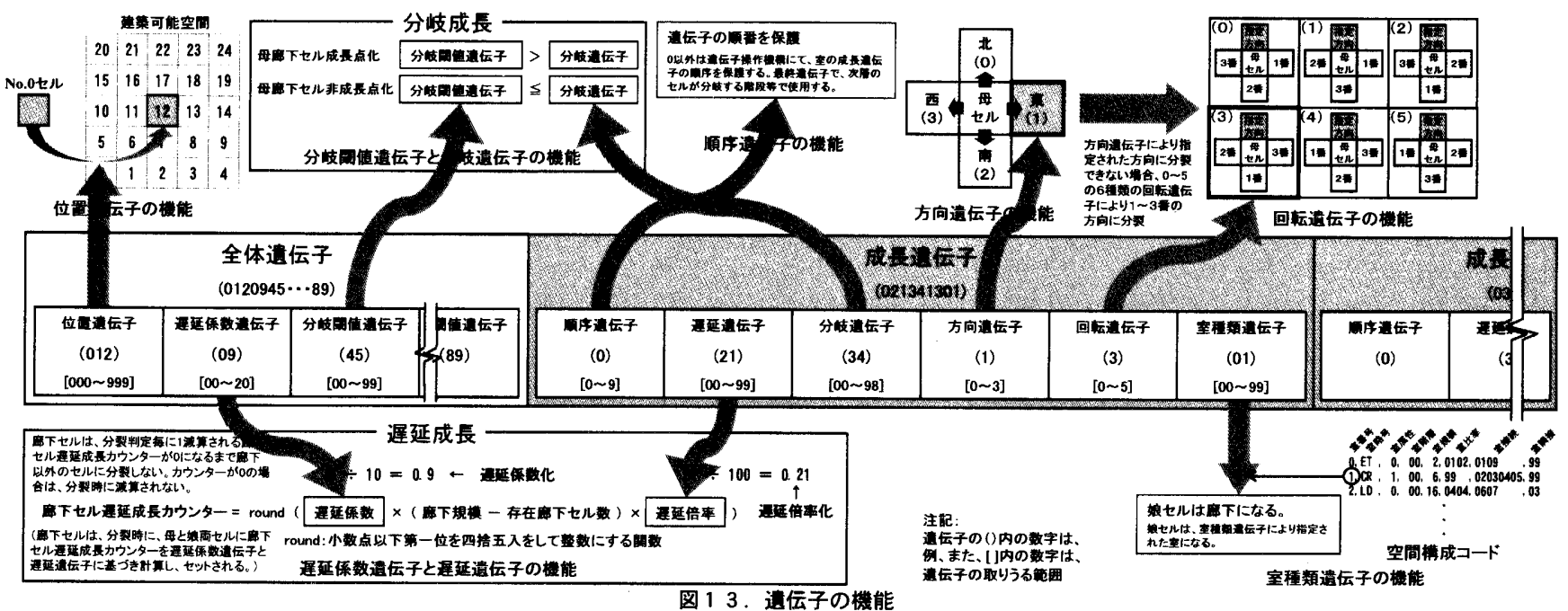

成長遺伝子は、セル 1 回の分裂に 1 組が必要になる。分化する室のあ る室は、1 つの分化室につき 1 つの分化室セルが分化するため、 1 組の 成長遺伝子の追加が必要となる。成長遺伝子組数は室毎に以ドの式によ り決定する。

(1)アプローチ以外の室

成長遺伝子組数 $=$ 指定空セル数 + 指定接続空数 -1

(2)アプローチ

成長遺伝子組数 $=0$ 㕌の建築可能空問モデュール数 -0 層の指定室セル数合計 $-1(2)$

図 7 の空閒構成コードから遺伝子を作成した例を表 2 に示す。

順序遺伝子は、階段など成長遺伝子の遺伝子操作機構における遺伝子 操作時に順序の保護が必要な室で使用する。順序は、1〜9で表し、成 長遺伝子の順序を問題としない室は、0とする。遅延遺伝子は、乱数に より0〜99を生成し、図 13 の遅延成長に示す様に、遅延倍率として、 遅延係数遺伝子と共に廊下セルの分裂時における遅延成長力ウンターの 算出に利用される。分岐遺伝子は、乱数により 0 〜 98 を生成し、図 1 3 の分岐成長に示す样に、分岐閾值遺伝子との比較により、母廊トセル 分裂時の成長点化の決定を行う。方向遺伝子は、母セルから分裂する娘 セルの方向を決定するものである。分裂方向は、図 13 の方向遺伝子の 機能に示す様に、ノイマン近傍の 4 方向を北 (0)、東 (1)、南 (2)、西 (3) とし、乱数により生成する。回転遺伝子は、セルの分裂を促進し成長を 早めるため、方向遺伝子により決定した方向に娘セルが分裂できない場 合、回転遺伝子の指定する方向に分裂を促す。回転遺伝子の指定する方 向は、図 13 の回転遺伝子の機能に示す様に、(0)〜 (5) の6種類とし、乱 数により生成する。室種類遺伝子は、図 13 の室種類遺伝子の機能の示 す様に、母セルから分裂する娘セルの室セルの種類を決定する。住宅空 間構成コードから接続する部屋を読み取り、乱数により組み込む遺伝子 の組を決定することにより生成する。

\section{(3) 遭伝子の利用}

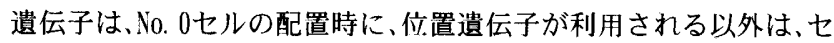
ルの分裂每に、そのセルの室の成長遗伝子が昇順で使用される。セルが 分裂できない場合は、次の同室セルの分裂に利用される。廊下セルの分 裂には、層每に用意されている全体遺伝子の遅延係数・分岐閾値遺伝子 と成長遺伝子を合わせて利用する。

\section{2-6-6. 分裂判定}

セルの分裂は、敷地、空間構成、遺伝子、属性、セルの置かれた環境、 分裂条件に基づき判定される。分裂判定の詳細は、図 14 に示す。

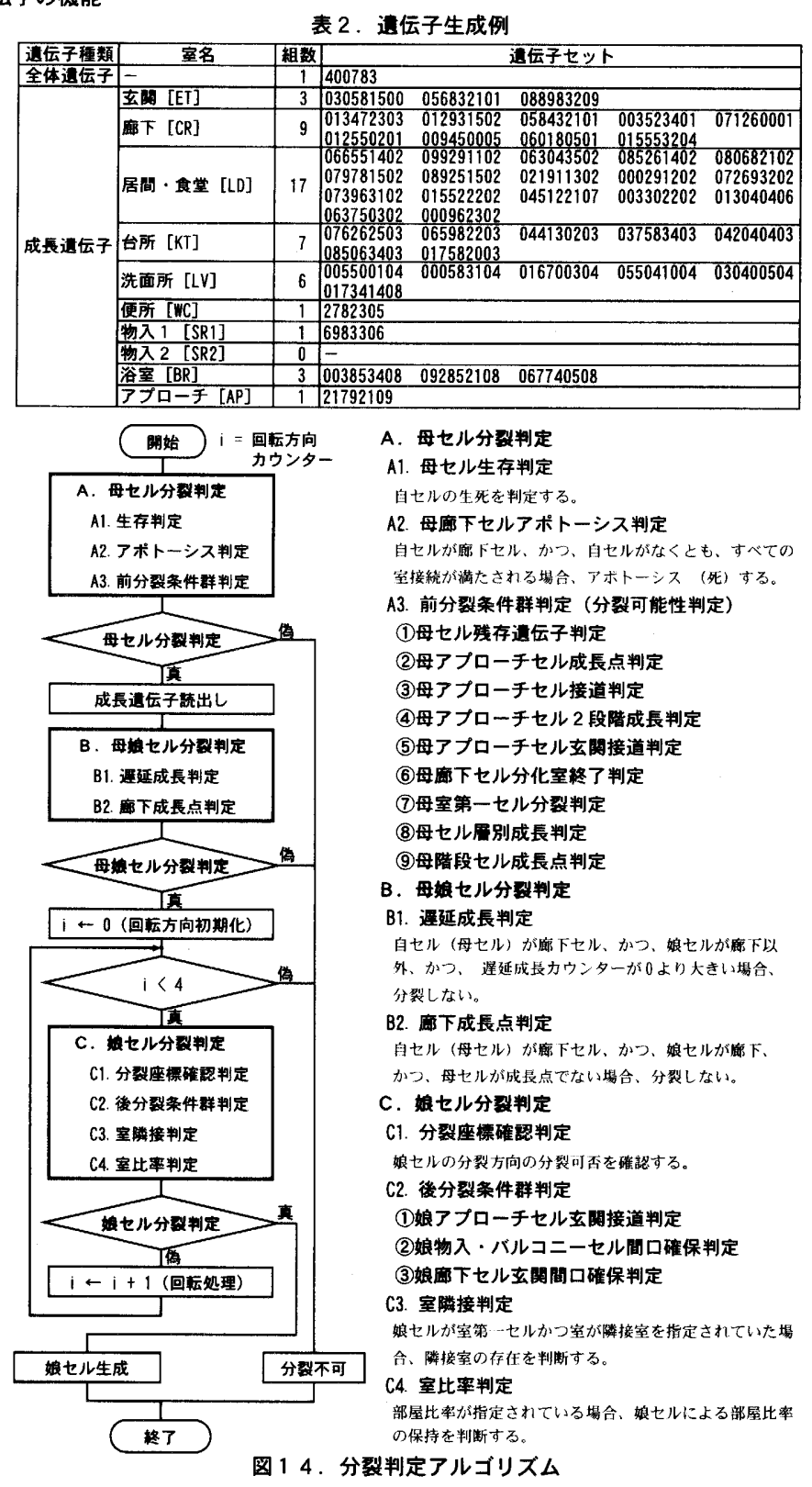

2-6-7. 住宅プランの成長

解积機構(空閒形成システム)による図 7 の住宅空間構成コード(外 部開口方位指定も含む) と表 2 の遺伝子生成例を用いた住宅プランの成 

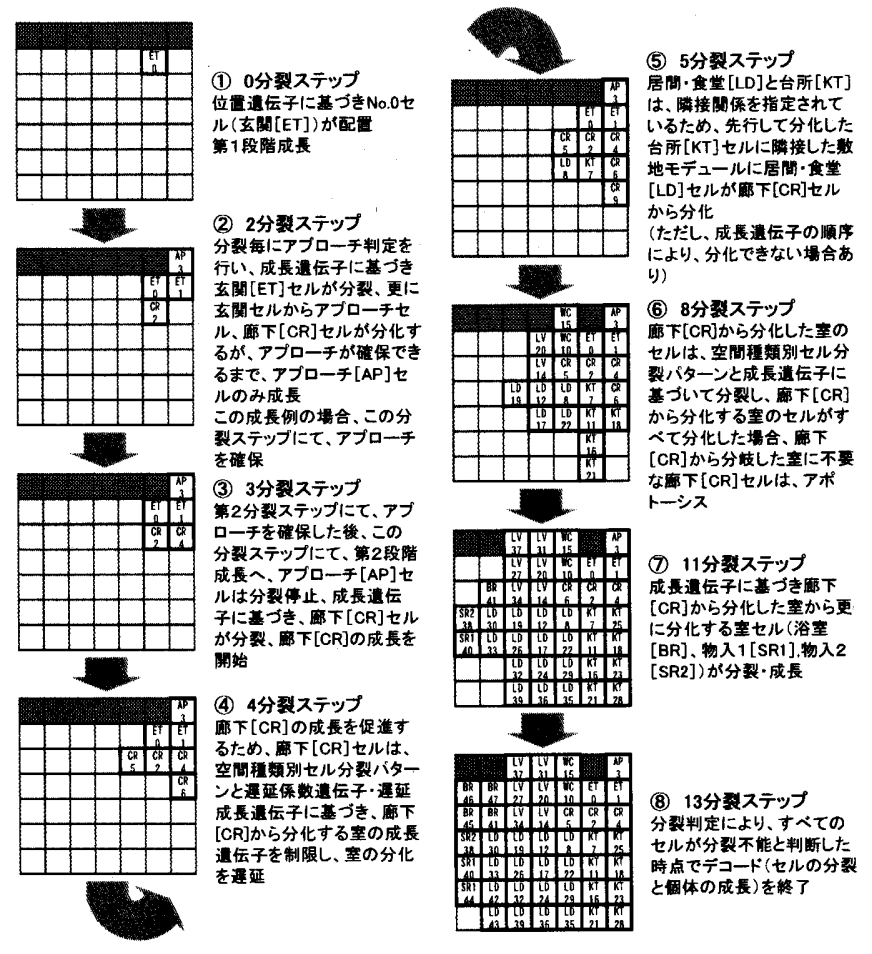

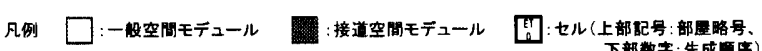
图 15 . 住宅プラン成長例

長例を図 15 に示す。

\section{2-7. 評価 [条件適応システム]}

評価は、室毎に室成長と外部開口を評価後、両評価値を合計し、室每 の評価値をすべて合計することにより、住宅プラン全体の評価值を算出 する。また、アブローチが確保できない場合は致死とし、評価値は 0 と する。

\section{2-7-1. 室成長評価値}

室成長評価値は、遺伝子をデコードした個体(住宅プラン)の環境(建 築可能空間)に対する成長の適志を評価する值である。住宅空間構成 コードに指定する指定室のすべてが完全に成長した場合、環境適伈度 (評価値)を最高とする。室成長評価值は、アプローチと廊下を除いた 室每に、住宅空間構成コードに指定されたセルがすべて生成された場合 を100とし、式 (3)により算出し、それらの合計とする。

室毎の室成長詊洒値 $=\frac{\text { 生成されたセル数 }}{\text { 空間構成コードにより指定されたセル数 }} \times 100$ (3)

\section{2-7-2. 外部開口評価値}

外部開山評価值は、外部開山部を必要とする指定室において、外部開 口部が作成叮能なセル(外部開山セル)の位置(方位) と数を評価する 值である。具体的には、図 8 の 5 .外部開口方位に示す様に、外部開口 セルが必要な方位に四方位の合計が100になるように值を設定する。こ れを指定外部開山値とする。外部開口評価値は、指定外部開口值毎に式 (4)により算出し、それらの合計とする。式 (4) の指定方位辺セル数は、 空間構成コードにより指定された室規模と室比率を基準に、実際に生成 された室の方向を考慮して、完全に成長した室の方位辽セル数とする。 指定外部開口值每の

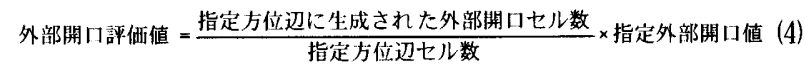

\section{2-8. 迹伝子操作機構 [条件適応システム]}

遺伝子操作機構は、致死遺伝子を除いた生き残り遺伝子が集団サイズ (150 個体) の2/3（100 個体）以上になった時点で動作する。2/3より
表 3. 这伝的アルゴリズムのパラメータ
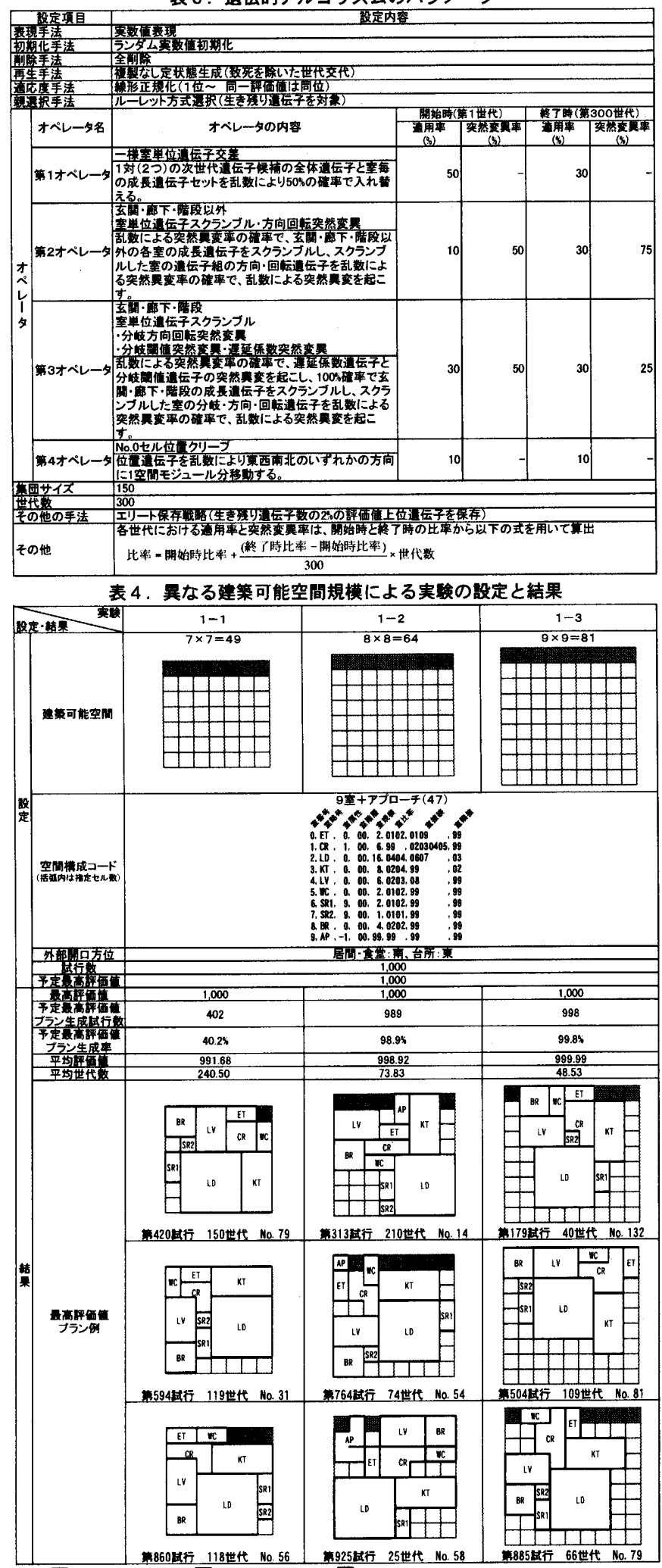

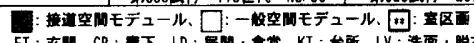

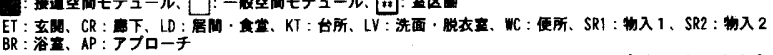
小さい場合は、致死遺伝子を乱数により新たに生成した遺伝子に置き換 え、解釈機構に集団サイズの遺伝子型を渡し表現型の評価を続ける。生 き残り遺伝子が集団サイズの $2 / 3$ 以上の場合、評価値から線形正規化に より適応度を算出する。適応度に基づき、エリート保存戦略とルーレッ 卜方式選択により、次世代遺伝子候補を選択する。次世代遺伝子候補 は、適応率に基づきランダムに表 3 に示す第 $1 \sim 4$ オペレータを適用す 
る。各オペレータの内容、その他のパラメータも表 3 に示す。遺 伝子操作は、室の遺伝子の構成を保存するため、主に室等の遺伝 子セット単位で一様交差とスクランブルを行う。遺伝子の構成・機 能、エリート保存戦略などにより、遺伝子の微小変化では、室の 分化位置や形状がほとんど変化しないことが予備実験により確認 されたため、本研究では、比較的人きな突然変異率を用いて集用 の多様性を確保している。

\section{3 . 検証実験}

住宅プラン生成システムの動作検証と動作傾向を確認するため、 本研究で作成した住宅プラン生成プログラムを用いて、異なる建 築可能空間規模と建物規模の設計条件により住宅プランを生成す る実験、リフォーム対応の検証として、建築可能空間と建物が同規 模となる（建築可能空閒モデュール数=室指定セル数）設計条件 により住宅プランを生成する実験、複数首の住宅プラン生成の検 証として、2 階建て住宅プランを生成する実験を行う。実験は、試 行前に予定最高評価値として、住宅プランが生成された際に得ら れる最高評価値を空間構成コードと外部開口方位指定から式 (3) と 式 (4)を利用して求め、予定最高評価值の住宅プランが生成された 時点でその試行を終え、新たな試行を開始し、予定最高評価値が 得られなかった試行は、最高評価値プランを試行結果とする。実 験毎に1,000回試行し、それらの試行の結果について、予定最高評 価值プランの生成数 (率) と生成されたプランの分析を行う。

\section{3-1. 異なる建築可能空間規模の実験}

建物規模は一定で、異なる建築叮能空間規模の住宅プランを生 成する。

実験の設定を表 4 上部に示す。建築可能空間は、 $7 \times 7 、 8 \times 8$ 、 $9 \times 9$ モデュールとし、空間構成は、 1 種類の空間構成を用い、外 部開口方位は、居間・食堂 [LD] に南を、台所 $[\mathrm{KT}]$ に東を指定する。

実験結果を表 4 下部に示す。最高評価値プラン例は、実験毎に 乱数により選択した3例をあげる。実験 $1-1$ に比べ $1-2 、 1-$ 3 の最高評価值プラン生成率が高く、平均世代数も実験 $1-1$ 3 で減少している。これは、建築規模に対し建築可能空間が大き くなると、プランの成長が容易になるため、予定最高評価值が得 られるプランの種類が多くなるためと考えられる。また、建築可 能空間に余裕があるにもかかわらず、アプローチがあまり生成さ れず接道空間モデュール寄りにプランが生成される傾向がある。 これは、アプローチがプラン本体の生成を妨害することが一因と と考えられる。

\section{3-2. 異なる建物規模の実験}

建築可能空間は一定で異なる建物規模の住宅プランを生成す る。

実験の設定を表 5 上部に示す。建築可能空間は、 $12 \times 10$ モ デュールとし、空間構成は、異なる空間規模の 3 種類の空間構成 を用い、外部開山方位は、居間・食掌 [LD]、洋室 1 [ERI]、洋室 2 [ER2] に南を、台所 [KT]に東を指定する。

実験結果を表 5 下部に示す。最高評価値プラン例は、肾験毎に 乱数により選択した 3 例をあげる。実験 $2-1$ と $2-2$ に比べ、 2 - 3 の最高評価值プラン生成率が極端に低下し、平均世代数が建 物規模と共に増大し実験 1 と同様な傾向が見られ、アプローチに関して も、実験 1 と同様の傾向が見られる。
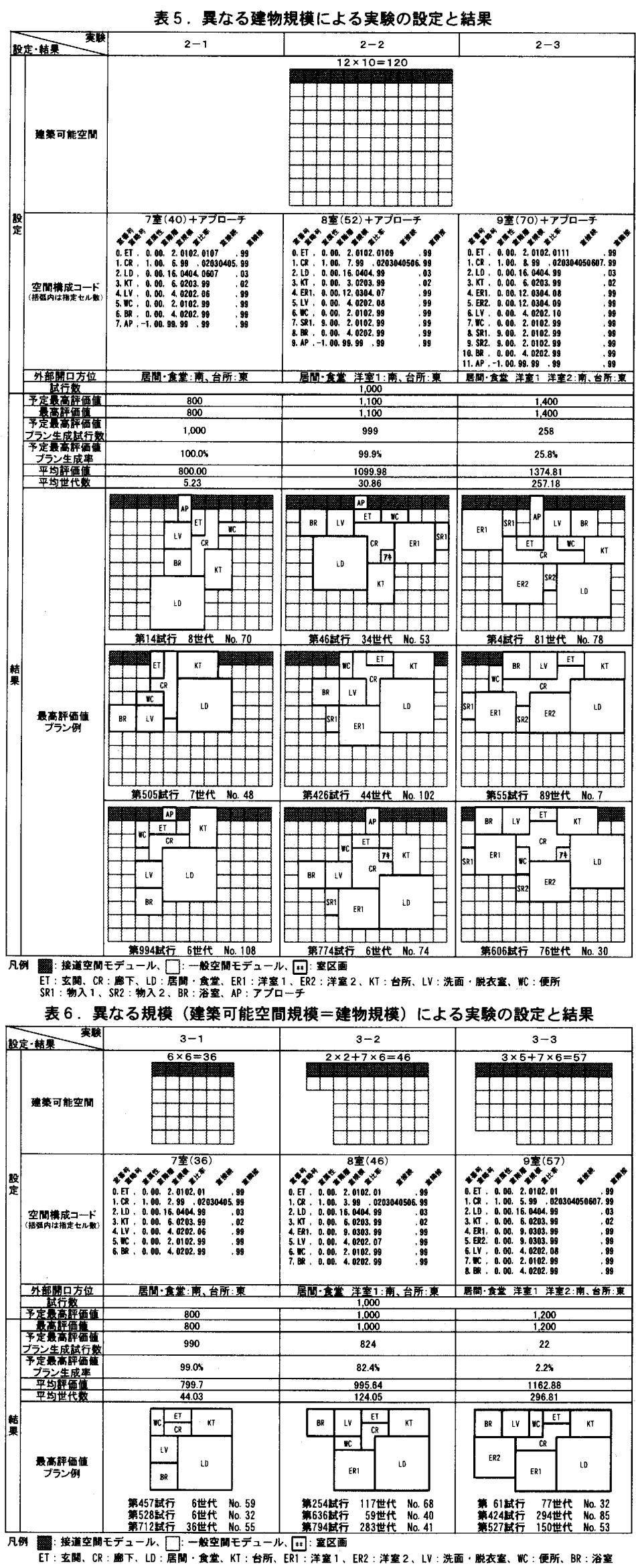

3-3. 異なる規模 (建築可能空間規模＝建物規模）による実験

住宅プラン生成法のリフォームへの応用を考慮して、建築可能空間 
と建物が同規模となる条件（建築可能空間モデュール数＝室指定セル 数）にて、3 種類の規模の異なる住宅プランを生成する。

実験の設定を表 6 上部に示す。建築可能空間は、 $6 \times 6 、 2 \times 2+7 \times$ $6 、 3 \times 5+7 \times 6$ モデュールとし、空間構成は、それらに対応した 3 種類 の空間構成を用い、外部開口方位は、居間・食堂 [LD]、洋室 1 [ER1] 、 洋室 2 [ER2] に南を、台所 [KT] に東を指定する。

実験結果を表 6 下部に示す。最高評価值プラン例は、実験毎に乱数に より選択した3例をあげる。実験 $3-1$ と $3-2$ に比べ、 $3-3$ の予定 最高評価值プラン生成率が極端に低下している。実験 2 と同じく部屋数 の多いプランの予定最高評価値プラン生成率が低い。この実験は、廊下 から分岐する室数が、実験 $2-1 \sim 3$ と同じであり、実験 2 とこの実験 から、廊下から分化する室数が多くなると、最高評価値プラン生成率が 低トすることがわかる。これは、本研究で構築した住宅プラン生成シス テムでは、廊下から分化する室の増加に伴い、これらの室が成長後に高 い評価値を得るための適当な間隔と向きを得ることが難しくなるためと 考えられる。

\section{3-4. 2 階建て住宅プラン生成実験}

複数層住宅プラン生成の検証として、2 階建て住宅プランを生成す る。

建築可能空間は、表 7 上部に示す1階（0層）と2階（1首）の規模が ほぼ同等な 2 層とし、空間構成は、一般的な戸建て住宅の空間構成で ある $4 \mathrm{LDK}+\alpha$ の空間構成を用い、外部開口方位は、居間・食堂 [LD] 、 和室 [JR]、洋室 1 のバルコニー1 [BL1]、洋室 2 のバルコニー2 [BL2]に 南を、台所 $[K T]$ に東を指定する。

実験結果を表 7 下部に示す。予定最高評価値を得た試行がなかったた め、評価値上位3位の試行結果を生成プラン例としてあげる。

この実験では、第422試行において2375の評価値を得られ、予定最 高評価值に近いプランを得ることができた。また、プラン生成率と平均 評価值が低い原因として、1階（0層）のプランが予定最高評価值を得 ていない状態で、2 階（1層）のプランを生成する試行が多いことが 考えられる。

\section{4. まとめ}

検証実験により、本研究にて構築した住宅プラン生成システムは、設 計条件が厳しく、複雑になることによるプラン生成率の低下などの問題 はあるが、一般的な住宅規模において動作することが確認された。

また、システムの構築を通して、生物の形態形成と環境適忘を模した 単位空間の分裂增殖による空間連結型モデルによる住宅プラン生成シス テムに関する設定とアルゴリズムの一例を示すことができた。

検証実験の観察と結果から、住宅プラン生成システムの予定最高評佂 值プラン生成率を高めるためには、次に示す改良が有効と考えられる。 (1)集団内における廊卜など多くの室が分化する室の成長分化パターンの 多様性を高める。

(2)すべての設計条件に共通な遺伝的アルゴリズムのパラメータではな

く、個々の設計条件に適応たパラメータを用いる。

(3)1階（0層）の評価值が高い遗伝子を保仔し、それらと2 階（1屏） の遺伝子を組合わせて試行を行うなど居別成長の手順を変更する。

\section{参考文献}

1) 吉田勝行:直方体分割図の電算機による作成法と設計計画への適用性に関する 研究 (1) 一值方体分割図の機械的な作成法とそのプログラム化一, 日本建築学 会論文報告集，第 293 号，pp. 105-115，1980.7

2) 古田勝行: 直方体分割図の電算機による作成法之設計計画への適用性に関する

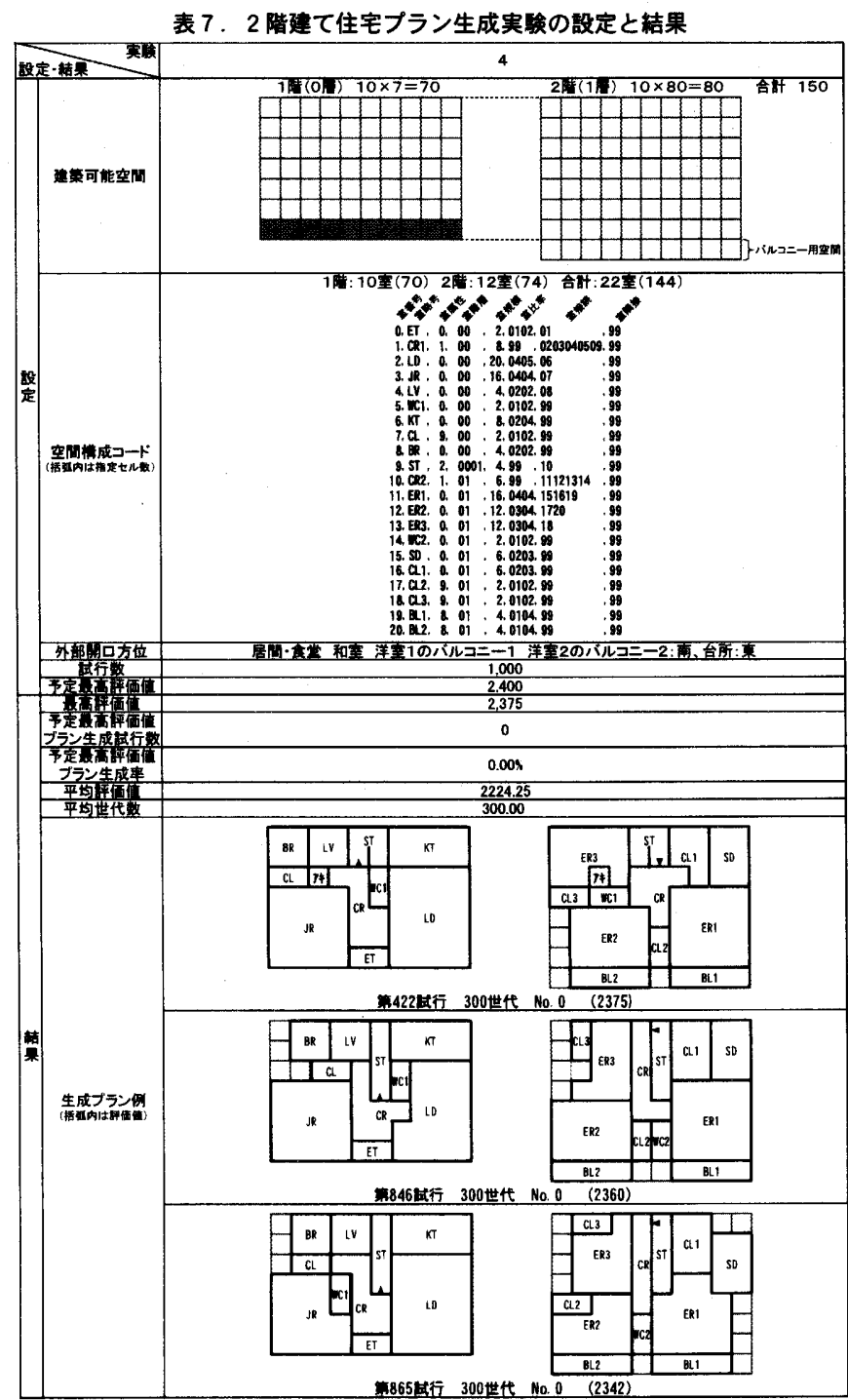

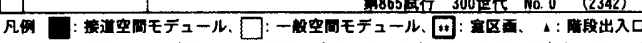

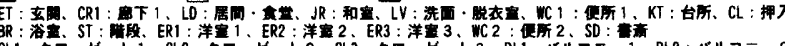
咶計画上の条件一，日本建築学会論文報告集，第295 号，pp. 103-113，1980.9 3) 古田勝行:非線形計画法による直方体分割図を母体とした最適平面の作成方に 関する研究 (1) - 非凸計画による最適規模の制付法とそのプログラム化一，H 本建築学会論文報告集，第 314 号, pp. 131-142，1982.4

4) 岡崎甚幸, 伊藤明宏 : 逐次近似型室配列・通路モデルの研究, 日本建築学会論 文報告集，第 339 号，pp. 90-100，1984.5

5) 上田完次：生物志向型生産システム，「.業調査会，1994.9

6) 青檥次:プラン作成と遺伝進化とのアナロジー一室配睓問題の遺伝進化アル ゴリズムによる解法一, 日本建築学会計画系論文集, 第481号, pp. 151-156, 1996. 3

7) 村岡直人, 肯木義次: 遺伝的アルゴリズムによる平面形状の最適化と設計ノウ 八ウの獲得, 日本建築学会計画系論文集, 第 497 号, pp. 111-115, 1997.7

8) 山遑友一郎, 河村廣, 谷明勲：人「.生命理論による住宅平面空閒構成, 日本建 築学会近畿支部研究報告集, pp. 565--568，1996

9) 山遑友一郎, 河村廣, 谷明勲: 知的人「生命の手法を用いた建築的立体構造形 成 (多重最適化システムによる最適解と初期乱数の影響)，第 20 回情報システ ム利用技術シンポジウム論文集, pp. 415-420，1997

10) Bruce Alberts, Alexander Johnson, Julian Lewis, Martin Raff, Keith Roberts, Peter Walter: 細胞の分子学 第 4版, ニュートンプレス, 2004. 12

11) 日経サイエンス編集部編:別冊日経サイエンス146 崩れるゲノムの常識 生 命科学の新展開, 日経サイエンス社, 2004.10 